\title{
Purification and Characterization of Flagella from the Alkalophile Bacillus firmus RAB
}

\author{
By ARTHUR A. GUFFANTI* AND HOWARD C. EISENSTEIN \\ Department of Biochemistry, Mount Sinai School of Medicine, City University of New York, \\ New York 10029, U.S.A.
}

(Received 1 February 1983; revised 22 April 1983)

Flagella from Bacillus firmus RAB, an alkalophilic bacterium, were purified to homogeneity. The flagella were shown to consist of a single protein subunit (flagellin) with an apparent molecular weight of 40000 . The amino acid composition of $B$. firmus RAB flagellin was similar to that of other bacilli except that the former had far fewer basic amino acids. The paucity of basic amino acids may render the flagella more stable at external $\mathrm{pH}$ values as high as 11.0 .

\section{INTRODUCTION}

The mechanism of cytoplasmic pH homeostasis (Guffanti et al., 1980; Krulwich et al., 1979; Mandel et al., 1980) and the characterization of intracellular enzymes (Ando et al., 1981; Horikoshi \& Akiba, 1982) in bacteria that grow at $\mathrm{pH}$ values as high as 11.0 have been extensively explored. Moreover, specific transmembrane carrier-mediated transport systems in these alkalophiles have been well characterized (Guffanti et al., 1978; Kitada \& Horikoshi, 1980). Extracellular enzymes of acidophilic thermophiles show both activity and stability at low $\mathrm{pH}$ and high temperature (Buonocore et al., 1976), while numerous extracellular enzymes from alkalophiles, such as protease (Kitada \& Horikoshi, 1976), polygalacturonate lyase (Kelly \& Fogarty, 1978), and amylase (Horikoshi \& Akiba, 1982), are very stable and optimally active at high $\mathrm{pH}$ values.

Little, if anything, is known about the structure or function of alkalophilic cell components directly exposed to the extreme external environment. Flagella represent an excellent model system in which to explore the effect of the external milieu upon structure and function. Thus, the molecular characterization of flagella isolated from an extreme alkalophile, Bacillus firmus RAB, was undertaken. Evidence is presented that the amino acid composition of flagellin purified from $B$. firmus RAB is quite similar to that of other bacilli, with one striking dissimilarity - the alkalophilic flagellin has a much lower content of basic amino acids.

\section{METHODS}

Growth. Bacillus firmus RAB was grown with shaking on L-malate medium at pH $10 \cdot 5$ (Guffanti et al., 1978), on a New Brunswick G25 rotary shaker.

Purification of flagella. Flagella were purified by following the techniques outlined by Smith \& Koffler (1971a). Highly motile cultures in the late-exponential phase of growth were harvested by centrifugation at $12000 \mathrm{~g}$ for $10 \mathrm{~min}$. The pellets were suspended in distilled $\mathrm{H}_{2} \mathrm{O}\left(30 \mathrm{~g}\right.$ wet $\left.\mathrm{wt}^{-1}\right)$ and shaken for $10 \mathrm{~min}$ with a New Brunswick W-8 twist-action shaker at about 500 strokes $\mathrm{min}^{-1}$. Intact cells were spun down at $6000 \mathrm{~g}$ for $30 \mathrm{~min}$ and the resulting supernatant was centrifuged at $16000 \mathrm{~g}$ for $20 \mathrm{~min}$. Flagella were then pelleted by centrifugation at $40000 \mathrm{~g}$ for $3 \mathrm{~h}$. The flagella were further separated from other cell fragments by centrifugation in a Beckman SW50.1 rotor at $12500 \mathrm{~g}$ for $30 \mathrm{~min}$ and then at $78000 \mathrm{~g}$ for $90 \mathrm{~min}$. The clear, gelatinous flagella in the upper part of the pellet were carefully removed and suspended in distilled water. The process of separation of the flagella from other cell fractions by differential centrifugation was repeated until pellets appeared completely clear. The flagellar protein (flagellin) was further purified by acidification with $\mathrm{HCl}$ to a final concentration of $1 \mathrm{mM}$. After $1 \mathrm{~h}$ at room temperature, the insoluble residue was removed by centrifugation at $104000 \mathrm{~g}$ for $1 \mathrm{~h}$. The supernatant 


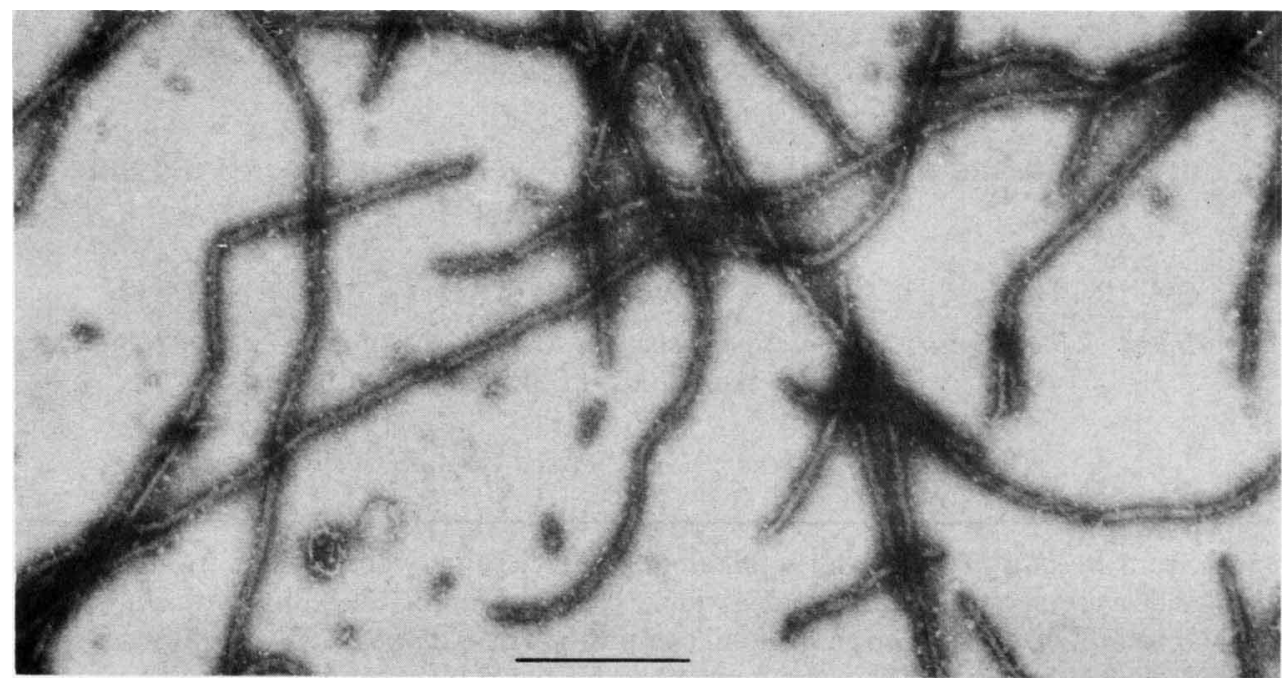

Fig. 1. Flagella isolated from Bacillus firmus RAB by mechanical agitation. The flagella were stained negatively with $1 \%(\mathrm{w} / \mathrm{v})$ phosphotungstic acid. The bar marker represents $0.5 \mu \mathrm{m}$.

was precipitated with $10 \%$ saturated $\left(\mathrm{NH}_{4}\right)_{2} \mathrm{SO}_{4}$ and then with $50 \%$ saturated $\left(\mathrm{NH}_{4}\right)_{2} \mathrm{SO}_{4}$ as described by $\mathrm{Koffler}$ $\&$ Kobayashi (1957). The $50 \%$ saturation precipitate was centrifuged at $30000 \mathrm{~g}$ for $30 \mathrm{~min}$ then resuspended in and dialysed against distilled water.

$P A G E$. Non-denaturing PAGE was run on $7.5 \%$ (w/v) polyacrylamide disc gels in an LKB vertical electrophoresis unit according to the procedure of Laemmli (1970). The SDS-PAGE used $10 \%(\mathrm{w} / \mathrm{v})$ polyacrylamide gradient gels. Flagellin samples were suspended in a solution containing $1 \%(\mathrm{w} / \mathrm{v}) \mathrm{SDS}, 10 \%(\mathrm{v} / \mathrm{v})$ glycerol, $5 \%$ (w/v) mercaptoethanol, $0.005 \%$ bromophenol blue, and $25 \mathrm{mM}$-Tris/HCl, $\mathrm{pH} 6.8$. The samples were heated for $2 \mathrm{~min}$ in a boiling water bath, cooled to room temperature, and applied to the gel. The proteins were stained with $0.25 \%$ Coomassie blue in acetic acid/methanol/water $(2: 9: 9$, by vol.) for $15 \mathrm{~min}$, and destained by diffusion with $10 \%(\mathrm{v} / \mathrm{v})$ methanol plus $7 \cdot 5 \%(\mathrm{v} / \mathrm{v})$ acetic acid. Protein was determined by the Lowry method using lysozyme as the standard.

Amino acid analysis. Purified flagellin was hydrolysed in $6 \mathrm{M}-\mathrm{HCl}$ and $0 \cdot 2 \%(\mathrm{v} / \mathrm{v})$ phenol for $24 \mathrm{~h}$ at $110^{\circ} \mathrm{C}$. Analysis was performed with a Beckman Model 119CL analyser.

Electron microscopy. Flagella were absorbed to Formvar-coated grids and negatively stained with $1 \%(\mathrm{w} / \mathrm{v})$ phosphotungstic acid, pH 7.0, as described by Lagenaur \& Agabian (1976). The grids were examined with a JEOL 100 electron microscope.

\section{RESULTS AND DISCUSSION}

Mechanical agitation of $B$. firmus RAB resulted in a suspension enriched for flagella (Fig. 1). After differential centrifugation of the suspended flagella, acidification and ammonium sulphate precipitation, only a single protein band was found in non-denaturing gels (Fig. 2). SDS-polyacrylamide gels showed one major protein band and traces of two other bands (Fig. 3). The flagellar subunit, henceforth referred to as $B$. firmus RAB flagellin, had an apparent molecular weight of 40000 , similar to the flagellins of other bacteria. The molecular weights of flagellins from other bacilli range from 30000 to 50000 (DeLange et al., 1976; Smith \& Koffler, 1971 b). Most species of bacteria, like B. firmus RAB, appear to have flagella composed of a single subunit (Smith \& Koffler, 1971 b), although some species may have more than one subunit (Lagenaur \& Agabian, 1976; Iino, 1969).

The amino acid composition of $B$. firmus RAB flagellin (Table 1) shared many characteristics with those of other Gram-positive bacteria (Smith \& Koffler, 1971 b). The content of glycine, alanine, leucine, isoleucine, threonine, aspartic acid and glutamic acid is high in B. firmus RAB flagellin and that of other bacilli (Smith \& Koffler, 1971b). In addition, little or no cysteine, tyrosine, tryptophan, proline and histidine residues are found in $B$. firmus RAB and related species. In contrast to neutrophilic bacilli, $B$. firmus RAB flagellin was devoid of serine. Most 
(a)

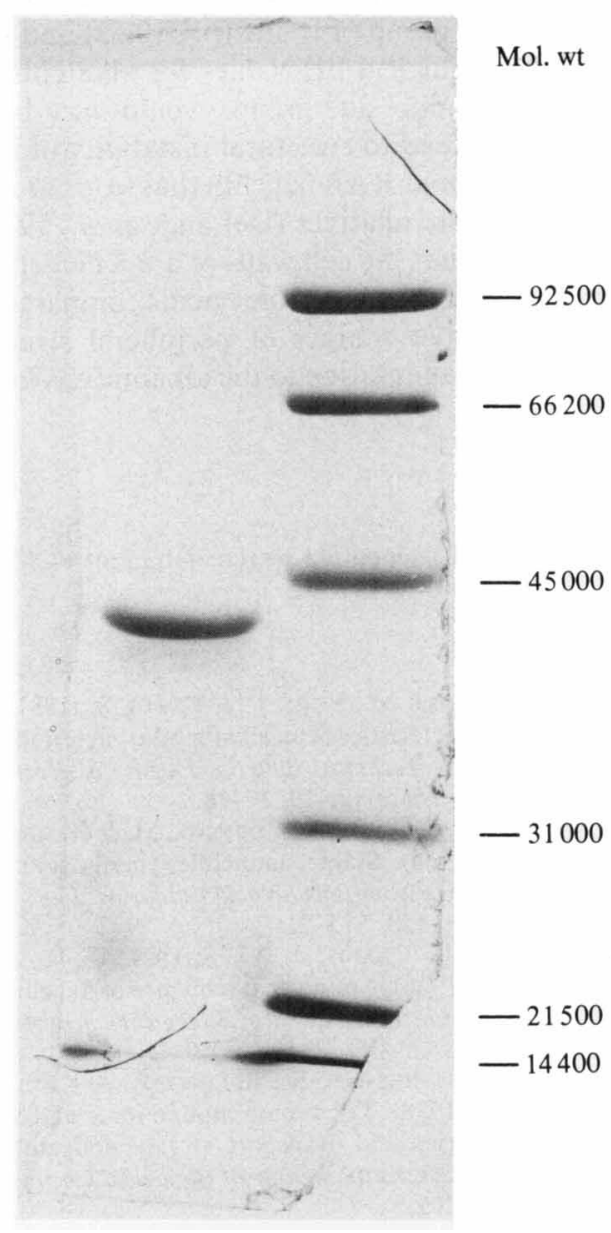

(b)

Mol. wt (a)

Fig. 3
Fig. 2

(b)

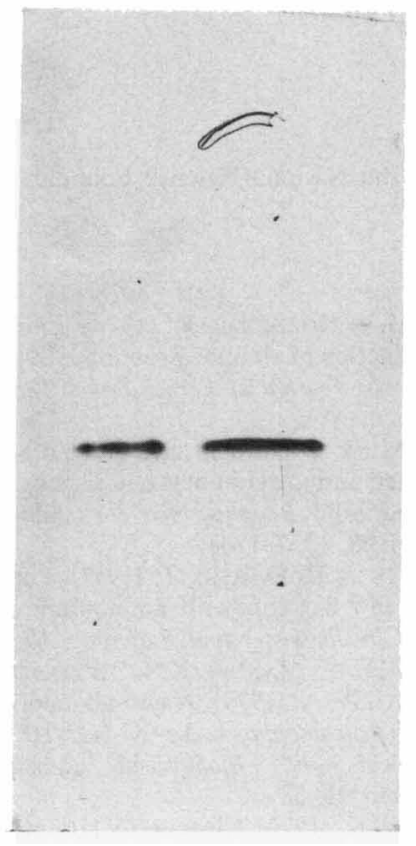
.

Fig. 2. Non-denaturing polyacrylamide gel of flagella purified from $B$. firmus RAB. (a) $10 \%$ saturated ammonium sulphate precipitate; $(b) 50 \%$ saturated ammonium sulphate precipitate.

Fig. 3. SDS-PAGE of purified B. firmus RAB flagellin. Purified flagella were acid treated as described in Methods and electrophoretically separated in $1 \%$ SDS gels. (a) Flagellin; $(b)$ protein standards in order of decreasing molecular weight: phosphorylase $b$, bovine serum albumin, ovalbumin, carbonic anhydrase, trypsin inhibitor, and lysozyme.

Table 1. Amino acid composition of B. firmus RAB flagellin

$\begin{array}{cccc}\text { Residue } & \begin{array}{c}\text { No. of residues } \\ \text { per molecule }\end{array} & \text { Residue } & \begin{array}{c}\text { No. of residues } \\ \text { per molecule }\end{array} \\ \text { Gly } & 41 & \text { Thr } & 43 \\ \text { Ala } & 84 & \text { Ser } & 0 \\ \text { Val } & 13 & \text { His } & 3 \\ \text { Leu } & 23 & \text { Lys } & 7 \\ \text { Ile } & 21 & \text { Arg } & 8 \\ \text { Met } & 3 & \text { Asp } & 66 \\ \text { Phe } & 2 & \text { Glu } & 34 \\ \text { Tyr } & 2 & \text { Pro } & 0 \\ \text { Trp } & 0 & \text { Cys } & 0 \\ & & & \end{array}$


strikingly, the flagellin of $B$. firmus RAB had far fewer basic residues than related neutrophiles. The $\varepsilon$-amino group of lysine (pK 10.53) and the guanidine group of arginine (pK 12.48) would be, at physiological $\mathrm{pH}$ values for alkalophiles, very near their $\mathrm{pK}$ values. Such a situation, where the amino side groups would vary between the charged and uncharged forms, might conceivably lead to structural instability of the flagellum. The relative paucity of basic amino acids in B. firmus RAB flagellin thus leads to an overall charge that is even more negative than in its neutrophilic relatives (DeLange et al., 1976). Interestingly, Horikoshi \& Akiba (1982) have pointed out that the cell walls of a Bacillus species grown at $\mathrm{pH} 10$ have a far greater content of aspartic, glutamic and uronic acids compared with the same cells grown at $\mathrm{pH} 7 \cdot 0$. Perhaps the highly negative charges of peripheral structures in $B$. firmus RAB and other alkalophiles represent an adaptation to the alkaline environment, repelling the negatively-charged hydroxyl ions.

This work was supported by research grant PCM 8121557 from the National Science Foundation.

\section{REFERENCES}

Ando, A., Yabuki, M., FujII, T. \& Fukui, S. (1981). General characteristics of an alkalophilic bacterium, Bacillus A-007. Technical Bulletin. Faculty of Horticulture, Chiba University 29, 17-28.

Buonocore, V., Caporale, C., deRosa, M. \& GambaCORTA, A. (1976). Stable, inducible, thermoacidophilic $\alpha$-amylase from Bacillus acidocaldarius. Journal of Bacteriology 128, 515-521.

Delange, R. J., Chang, J. Y., Shaper, J. H. \& GLAZER, A. (1976). Amino acid sequence of flagellin of Bacillus subtilis 168. Journal of Biological Chemistry 251, 705-711.

Guffanti, A. A., Susman, R., Blanco, R. \& KrulWICH, T. A. (1978). The proton motive force and $\alpha$ aminoisobutyric acid transport in an obligately alkalophilic bacterium. Journal of Biological Chemistry 253, 708-715.

Guffanti, A. A., Blanco. R., Benenson, R. A. \& KRULWICH, T. A. (1980). Bioenergetic properties of alkaline-tolerant and alkalophilic strains of Bacillus firmus. Journal of General Microbiology 119, 79-86.

HoRikoshI, K. \& AkIBA, T. (1982). In Alkalophilic Microorganisms. A New Microbial World, pp. 75-77. Tokyo: Japan Scientific Societies Press \& SpringerVerlag.

IINO, T. (1969). Genetics and chemistry of bacterial flagella. Bacteriological Reviews 33, 454-475.

Kelly, C. T. \& FogarTy, W. M. (1978). Production and properties of polygalacturonate lyase by an alkalophilic microorganism Bacillus sp. RK9. Canadian Journal of Microbiology 24, 1164-1172.
KitaDA, M. \& HoRIKoshi, K. (1976). Effect of pH on the production of alkaline proteinase by alkalophilic Bacillus sp. Journal of Fermentation Technology 54, 579-586.

Kitada, M. \& Horikoshi, K. (1980). Sodium ionstimulated amino acid uptake in membrane vesicles of alkalophilic Bacillus No. 8-1. Journal of Biochemistry 88, 1757-1764.

Koffler, H. \& Kobayashi, T. (1957). Purification of flagella and flagellin with ammonium sulfate. $A r$ chives of Biochemistry and Biophysics 67, 246-248.

KrUlwich, T. A., MANDEl, K. G., Bornstein, R. F. \& Guffanti, A. A. (1979). A non-alkalophilic mutant of Bacillus alcalophilus lacks the $\mathrm{Na}^{+} / \mathrm{H}^{+}$antiporter. Biochemical and Biophysical Research Communications 91, 58-62.

LAEMMLI, U. K. (1970). Cleavage of structural proteins during the assembly of the head bacteriophage $\mathrm{T} 4$. Nature, London 227, 680-685.

Lagenaur, C. \& Agabian, N. (1976). Physical characterization of Caulobacter crescentus flagella. Journal of Bacteriology 128, 435-444.

Mandel, K. G., Guffanti, A. A. \& Krulwich, T. A. (1980). Monovalent cation/proton antiporters in membrane vesicles from Bacillus alcalophilus. Journal of Biological Chemistry 255, 7391-7396.

Smith, R. W. \& Koffler, H. (1971 a). Production and isolation of flagella. Methods in Microbiology $\mathbf{5 A}$, 165-172.

SMITH, R. W. \& KoffleR, H. (1971b). Bacterial flagella. Advances in Microbial Physiology 6, 219-339. 